Uniwersytet Gdański

\title{
Figura wroga $w$ ideologii i propagandzie XX-wiecznych totalitaryzmów - przyczynek do dyskusji
}

\begin{abstract}
Streszczenie
Bez względu na rodzaj reżimu totalitarnego, ani jego „brunatna”, ani „czerwona” odmiana nie mogłaby zdobyć uładzy, a na pewno tej władzy utrzymać w krótszym lub dłuższym czasie bez wykreowania u przestrzeni publicznej przysłowiowej figury uroga. „Wróg i wrogowie” stanowili niezbędną pożyukę dla systemu politycznego, opartego w znacznym stopniu na obronie i walce z mniej lub bardziej konkretnymi przeciunikami nowego ustroju. Dlatego też „produkowanie” obrazów uroga należy zaliczyć do jednego z podstawouych zadań propagandy w systemach niedemokratycznych XX wieku. Kategoryzacja wrogów, mimo że przy różnych okazjach jej dokonywano, w praktyce polityczno-propagandowej, jak się wydaje, nie odgrywała aż tak ważnej roli w obu odmianach reżimów totalitarnych. Liczył się zausze bieżący interes polityczny, który potrafił prowadzić do nagłej zamiany „przyjaciół” na „wrogów” i odurotnie.
\end{abstract}

Słowa kluczowe: propaganda, figura wroga, systemy totalitarne, XX wiek.

\section{The enemy figure in ideology and propaganda of the $20^{\text {th }}$ century totalitarian systems - foundation for the debate}

\begin{abstract}
Regardless of the type of a totalitarian regime, neither its "brown" nor "red" variety could have seized power, or surely remain in power for a shorter or longer period of time, if it was not for the creation of the proverbial enemy figure in public space. "Foe and enemies" constituted a necessary fuel for a political system which was based to certain extent on a defense and fight with more or less specific opponents of the new regime. This is why "producing" images of the enemy should be considered as one of the main propaganda tasks in the $20^{\text {th }}$ century non-democratic systems. In the political-propaganda practice, enemy categorization, although it did take place on various occasions, did not play such an important role in any variety of a totalitarian regime. What counted was the current political business which could lead to a sudden switch from "friends" to "enemies", and vice versa.
\end{abstract}

Key words: propaganda, enemy figure, totalitarian systems, twentieth century.

W przedstawionych rozważaniach zostanie przybliżony sposób mówienia o „wrogu-wrogach", ideologicznym i praktycznym elemencie prowadzenia polityki przez ugrupowania oraz ruchy o charakterze niedemokratycznym w XX wieku (zwłaszcza 
do jego połouy), zarówno na etapie walki o władzę, jak i już u czasie jej sprawowania. Przykłady zostaną zaczerpnięte z wypowiedzi politycznych liderów dwóch głównych odmian XX-wiecznych totalitaryzmów - faszyzmu i komunizmu ${ }^{1}$, ze szczególnym uwzględnieniem retoryki występującej, z jednej strony w PRL-ouskiej i sowieckiej odmianie reżimu niedemokratycznego, z drugiej zaś w totalitaryzmie faszystouskich Niemiec.

Wśród poruszonych tu zagadnień znajdą się kwestie dotyczące: przybliżenia ogólnych założeń strategii polityczno-propagandowej, w której poczesne miejsce zajmowały sprawy kreowania i wykorzystywania tak zwanej figury wroga; kategoryzacji wrogów; sposobu ich opisu, który w tym wypadku musi być podany w formie mocno zawężonej. Na tym tle warto też zadać sobie pytanie o aktualność zagrożeń, które były zuiązane z wykorzystywaniem w propagandzie tytułowej figury; sposobu politycznego komunikowania, który i dzisiaj, jak się wydaje, nie tylko w państwach niedemokratycznych, niestety odnosi sukcesy².

Wskazując na miejsce głównych intelektualnych inspiracji w polskiej przestrzeni badawczej, na pierwszym miejscu, w opinii autora tych rozważań, należy wymienić prace Michała Głowińskiego i Eugeniusza Cezarego Króla. Naukoucy ci w sposób niezwykle kompetentny i rzetelny badawczo wpisali się w nurt nie tylko poszukiwań odpowiedzi, ale także stawiania pytań na tematy związane z funkcjonowaniem propagandy u reżimach niedemokratycznych XX wieku. Zwrócili między innymi uwagę na znaczenie wykorzystywania w komunikacji politycznej interesującej nas figury. Pieruszy, skupiając się na analizie języka nowomowy w Polsce Ludowej ${ }^{3}$, drugi (szczególnie) na przybliżeniu działań aparatu propagandy NSDAP w Republice Weimarskiej i III Rzeszy4.

1 Zob. więcej na temat rozumienia pojęcia komunizmu m.in. w: W. Kajtoch, Bracia Strugaccy (zarys twórczości), TAiWPN Universitas, Kraków 1993, s. 199-200.

${ }_{2}$ Zob. przemyślenia na temat uspółczesnego języka polityki i niebezpieczeństu zuiązanych z możliwością wykorzystywania obecnie technik propagandowych mających rodowód w XX wieku systemach totalitarnych: M. Głowiński, Język siecze (rozmowa prowadzona przez Katarzynę Czarnecką), „Polityka”, 14 IX 2016, s. 24-25; E.C. Król, Joseph Goebbels i jego „Dzienniki” [w:] Joseph Goebbels. Dzienniki, t. 1: 1923-1939, Świat Książki, Warszawa 2013, s. XLIX-L; idem, Stowo do tomu trzeciego „Dzienników” Josepha Goebbelsa [w:] Joseph Goebbels. Dzienniki, t. 3: 1943-1945, Warszawa 2014, s. XII-XIII; J. Bocheński, Po co nam „Dzienniki” zbrodniarza, szefa propagandy Trzeciej Rzeszy, „Gazeta Wyborcza”, 5-6 VII 2014, s. 24-26; O propagandzie. Jak nami manipuluja, „Newsueek Extra” 2017, nr 2.

${ }^{3}$ Najważniejsze prace M. Głowińskiego pośuięcone analizie języka propagandy Polski Ludouej zostały uymienione w „Wprowadzeniu” do książki: M. Głowiński, Zła mowa. Jak nie dać się propagandzie, Wielka Litera, Warszawa 2016, s. 9-10; nie można też nie uspomnieć o innym badaczu języka polityki czasów PRL - J. Bralczyku, który m.in. w takich pracach pochylił się nad interesującym nas zagadnieniem: J. Bralczyk, O języku polskiej polityki lat osiemdziesiątych i dziewięćdziesiatych, Trio, Warszawa 2003; idem, O języku polskiej propagandy politycznej lat siedemdziesiatych, Trio, Warszawa 2001.

${ }_{4}$ Zob. m.in. prace: E.C. Król, Propaganda i indoktrynacja narodowego socjalizmu $w$ Niemczech 1919-1945. Studium organizacji, treści, metod i technik masowego oddziaływania, Instytut Studióu Politycznych Polskiej Akademii Nauk-Rytm, Warszawa 1999; idem, Polska i Polacy w propagandzie narodowego socjalizmu w Niemczech 1919-1945, Instytut Studiów 
Figura wroga w ideologii i propagandzie XX-wiecznych totalitaryzmów...

\section{Uwagi wstępne}

Figura uroga jest nie tylko głóunym elementem propagandy marcouej czy - ucześniej stalinouskiej ${ }^{5}$, jest fundamentem całej propagandy komunistycznej... Bez postaci uroga nie ma u ogóle propagandowego dyskursu komunistycznego, jest on bez niej nie do pomyślenia. Wróg określa wizję świata, sposoby myślenia i mówienia [...]. Wróg nie tylko jest «uszelkiej maści», także - niejedno ma imię. Gdy nie ma urogów rzeczywistych lub nie zagrażają i nie mają wpływu na praktykę, trzeba ich sztucznie tuorzyć, uymyślić. Wróg obecny jest zausze, bo cały świat komunistyczny jest światem przeciw ${ }^{6}$.

Ten cytat zaczerpnięty z pracy Michała Głowińskiego nie tylko trafnie charakteryzował rolę propagandową figury wroga w codziennej praktyce politycznej państu komunistycznych, ale także mógłby celnie oddawać założenia funkcjonowania propagandy w pozostałych odmianach systemu totalitarnego, na czele z III Rzeszą.

W ruchu nazistouskim, jak pisał z kolei Eugeniusz C. Król:

Należało zaakceptować inscenizację rzeczywistości z kontrastującym podziałem na złe i dobre moce. Propaganda NSDAP posługiuała się przede uszystkim obrazami wroga absolutnego, ujętego zarówno w formie abstrakcyjnych „sił antynarodowych”, jak też w postaci konkretnych przeciuników politycznych?

W Mein Kampf niemiecki dyktator pisał o potrzebie ujęcia syluetki wroga w taki sposób, by „przeciuników, nawet bardzo różniących się od siebie, sprouadzić do jednego mianownika" ${ }^{8}$. Chodziło tutaj o zastosowanie techniki propagandowej, zwanej „formułą redukcji i uniwersalizacji cech wroga”, której stosowanie miało, jak pisał przywódca Narodowosocjalistycznej Niemieckiej Partii Robotników (NSDAP), „ułatwić wiarę u słuszność sprawy i wzmóc zaciętość wystąpień przeciuko oponentowi”.

Charakterystyki propagandy reżimów totalitarnych z reguły wymieniają wśród ich podstawowych cech występowanie interesującej nas figury retoryczno-propagandowej ${ }^{10}$. Norman Davies pisał:

Politycznych Polskiej Akademii Nauk, Warszawa 2006; idem, Joseph Goebbels i jego „Dzienniki”..., op. cit., s. IX-L; idem, W poszukiwaniu modelu propagandy totalnej [w:] Propaganda $w$ systemach demokratycznych i niedemokratycznych, red. J.W. Wołoszyn, Wydaunictwo KUL, Lublin 2015, s. 17-45.

${ }^{5}$ Literatura przedmiotu pośuięcona propagandzie stalinouskiej i „marcowej” wymieniona u pracach: J. Wojsław, Obraz teraźniejszości w propagandzie komunistycznej Polski lat 1949-1954. Zarys problematyki, Wydawnictuo UG, Gdańsk 2009, s. 15-38; idem, „Polityka” Mieczysława Rakowskiego wobec „marcowej” (1968) mowy nienawiści [w:] Media, Biznes, Kultura. Społeczna i polityczna rola mediów, red. M. Łosiewicz, A. Ryłko-Kurpieuska, TrueSign-Novae Res, Kinvara Co. Galuay-Gdynia 2015, s. 121-142.

${ }^{6}$ M. Głouiński, Zła mowa ..., op. cit., s. 222.

7 E.C. Król, Propaganda i indoktrynacja narodowego socjalizmu..., op. cit., s. 87.

${ }^{8}$ Cyt. za: ibidem, s. 46.

${ }^{9}$ Ibidem.

${ }^{10}$ Zobacz szerzej na ten temat: H. Arendt, Korzenie totalitaryzmu, Świat Książki, Warszawa 2014, s. 423-466; K. Kersten, Wstęp do polskiego wydania [w:] S. Courtois, N. Werth, J.-L. Panne, A. Paczkouski, K. Bartosek, J.-L. Margolin, Czarna księga komunizmu. Zbrodnie, terror, 
[...] żaden totalitarny reżim nie mógł mieć nadziei, że uda mu się umocnić ułasne złe zamiary bez innego zła, z którym mógłby się zmagać. Narodziny faszyzmu u Europie spadły komunistom jak z nieba, ponieważ bez niego mogliby się odwoływać jedynie do bardziej odległych złych mocy liberalizmu, imperializmu i kolonializmu. Faszyści nigdy nie przestali szukać dla siebie usprawiedliwienia, mówiąc o krucjacie przeciwko bolszewizmowi, komuniści - o «walce z faszyzmem» ${ }^{11}$.

Istota totalitaryzmu osadzała się również na nieustannym tworzeniu wrażenia uśród mas, że grozi im ze strony różnych, bardziej lub mniej rozpoznanych sił, śmiertelne niebezpieczeństwo. Ów mechanizm oparty na budowie w przestrzeni społecznej psychologii nienawiści reżimy totalitarne wykorzystywały do truałego podtrzymywania uśród społeczeństu podniecenia, stałej gotowości do walki z bardziej lub mniej wyimaginowanym wrogiem, nieustannego baczenia na środowisko, w którym się przebywa.

Co do sposobu kategoryzacji wrogów należy na ustępie przypomnieć chyba najbardziej rozpowszechnioną w praktyce politycznej totalitaryzmóu regułę ich podziału na dwie grupy: wrogów wewnętrznych i zewnętrznych; co oczywiście nie musiało oznaczać u codziennej aktywności propagandowej tworzenia jeszcze innych subkategorii, czy też swobodnego ich przenikania, w zależności od aktualnych potrzeb.

Jeszcze inną kategoryzację przeciuników reżimów niedemokratycznych zaproponował E.C. Król. Posługując się dokonaniami polskiej kinematografii lat stalinizmu, rysowanymi w filmach powstałych w okresie obowiązywania w sztuce założeń socrealizmu ${ }^{12}$, wyróżnił on: „wrogów” tak zwanej pieruszej kategorii, czyli „absolutnych”, „śmiertelnych” i „odwiecznych”; ich lokalne - drugorzędne odpowiedniki; niejako trzeci poziom mieli stanowić z kolei „pomocnicy wroga, «subiektywnie» często nieszkodliwi, ale «obiektywnie» niebezpieczni, wymagający nieustannej podejrzliwości i czynnego przeciudziałania"13.

Jak pisze dalej historyk:

Obecność uroga na srebrnym ekranie, z natury rzeczy wyolbrzymionego i zdemonizowanego, miała wyzualać nieufność, nienawiść i odrazę wraz z towarzyszącym nieodmiennie uczuciem strachu, a także fobiami i resentymentami. Z punktu widzenia socjotechniki totalitarnej władzy była to kombinacja korzystna. Dawała bowiem możliwość pożądanego sterowania nastrojami społecznymi. Stanouiła róunież swoisty czynnik integracyjny, gdyż owe seanse

prześladowania, Prószyński i S-ka, Warszawa 1999, s. 11-12; J. Wojsław, Ideologizacja przekazów ikonograficznych o tematyce zdrowotnej w czasach PRL: w poszukiwaniu wizualnego stereotypu, „Zeszyty Prasoznawcze” 2015, nr 2(222), s. 406-407 (tam też podano szerszą literaturę przedmiotu).

${ }^{11}$ N. Davies, Europa. Rozprawa historyka z historia, Znak, Kraków 1998, s. 1005.

${ }^{12}$ Więcej na temat ideologicznych założeń socrealizmu i ich praktycznego realizowania w Polsce lat stalinizmu (tam też podana szersza literatura przedmiotu) u pracy: J. Wojsław, Ideologizacja przekazów ikonograficznych..., op. cit., s. 405-422.

${ }_{13}$ E.C. Król, Formuła wroga w polskim filmie socrealistycznym (1947-1956), „Przegląd Historyczny" 2007, z. 2, s. 240. 
Figura wroga w ideologii i propagandzie XX-wiecznych totalitaryzmów...

nienawiści przyczyniały się do mobilizacji dużych grup ludzkich, wytwarzając poczucie czy raczej złudzenie więzi między rządzącymi a rządzonymi ${ }^{14}$.

Ważnym spostrzeżeniem, dobrze oddającym podstawowe cechy - nie tylko w polskim filmie lat stalinizmu, rysowanego przez propagandę komunistyczną obrazu wroga - jest stwierdzenie mówiące o „wrogu” odpowiednio zuniwersalizowanym, zredukowanym i ideowo jednorodnym. „Chodziło o to - jak pisze historyk - aby wizerunek uroga był zrozumiały dla szerokich mas. Powinien więc zawierać cechy uspólne, a zarazem nieliczne i bardzo wyraziste..."15. Podobnie przedstawiała się rzecz ze sposobem opisywania figury wroga w III Rzeszy, gdzie jedną z podstawowych technik propagandowych uczyniono zasadę rysowania jego według uproszczonej i nacechowanej negatywnymi emocjami kalki.

\section{Figura wroga i jego typy w propagandzie nazistowskich Niemiec}

W przypadku ideologii nazistouskiej szczególne miejsce przypadło, jak pisał Leszek Kołakouski we ustępie do Dzienników Victora Klemperera, budowie „nienawiści do Żyda, u pokazywaniu, że uszystkiemu złu świata Żyd jest winien"16. Sam Hitler używał często pojęcia ,żydouski” zamiennie z inną ogólną kategorią wroga, jaką stanowili „marksizm i marksiści”. Jeden z jego biografów stuierdził:

Stosounie do potrzeb mógł on ostrzegać przed «międzynarodouym żydouskim urogiem śuiata», a innym razem przed «marksistousko-internacjonalistycznym zatruwaniem ludu». Czasami zaś używał obu tych nienawistnych określeń w jednym uspólnym sformułowaniu: «Żyd jest i pozostanie urogiem świata, a jego broń, czyli marksizm, dżumą ludzkości» ${ }^{17}$.

W jednym i drugim przypadku pojęcia te mogły zarówno charakteryzować „wrogów” wewnętrznych, jak i zewnętrznych. Stały się podstawowym elementem ${ }^{18}$ wystąpień publicznych nazistowskich liderów oraz rozpowszechnianych przez aparat propagandy treści ${ }^{19}$, gdzie dla podkreślenia niewątpliwego sojuszu obu wrogich sił

\footnotetext{
14 Ibidem, s. 239-240.

15 Ibidem, s. 240.

${ }^{16}$ L. Kołakouski, Zapiski podczłowieka z żótta tata [w:] V. Klemperer, Chcę dawać świadectwo aż do końca. Dzienniki 1933-1938, t. 1, TAiWPN Universitas, Kraków 2000, s. XXXII. 17 V. Ullrich, Hitler. Narodziny zła 1989-1939, Prószyński i S-ka, Warszawa 2015, s. 268.

${ }^{18}$ V. Klemperer wielokrotnie w swoich „Dziennikach” wraca do kwestii budowy w społeczeństuie niemieckim przez reżim nazistouski przeświadczenia o „uszechogarniającej winie Żyda”; zob. V. Klemperer, Chcę dawać świadectwo aż do końca. Dzienniki 1943-1945, t. 3, TAiWPN Universitas, Kraków 2000, s. 94-95, 98.

${ }_{19}$ Pewnym wyjątkiem u ciągłości prowadzenia jednoznacznie negatywnej kampanii „antymarksistouskiej”, którą utożsamiano z istnieniem i polityką państwa sowieckiego, były lata 1939-1941, kiedy to po podpisaniu traktatu Ribbentrop-Mołotow w sierpniu 1939 roku dwie dyktatury zawarły taktyczny pokój.
} 
używano często zbitki słownej - „żydowski bolszewizm”20. Sam Hitler, jak stwierdził brytyjski historyk Ian Kershaw, miał traktować już z początkiem lat 20. ubiegłego wieku pojęcia „marksizm” i „Żyd” jako synonimy ${ }^{21}$. I w tym uzględzie nie zmienił on poglądu do końca życia.

Obok uspominanych, tak fundamentalnych dla ruchu nazistowskiego kategorii, listę tę należy uzupełnić o paletę innych przeciuników. Jeszcze na etapie walki o władzę, do stycznia 1933 roku w katalogu tym pojawili się kojarzeni z Republiką Weimarską, która już sama u sobie była synonimem „złych mocy”, przedstawiciele jej establishmentu, w którego skład wchodzili politycy Socjaldemokratycznej Partii Niemiec (SPD) i innych ugrupowań weimarskiej sceny politycznej ${ }^{22}$. Dlatego też jednym z głównych sloganów przygotowanych na lipcowe wybory parlamentarne w 1932 roku dział propagandy NSDAP uczynił hasło „Precz z układem², jego partiami i ich dygnitarzami”24, czyli systemem politycznym, w tym konstytucją Republiki Weimarskiej.

Już po przejęciu władzy Heinrich Himler ${ }^{25}$, tłumacząc celowość istnienia obozów koncentracyjnych w III Rzeszy mówił, że „podstępni przeciunicy podjęli na nowo swoją destrukcyjną robotę"26, dlatego należało ich izolować w obozach. Jak pisze historyk: „Według Himmlera narodowi niemieckiemu nadal groziło śmiertelne niebezpieczeństwo, gdyż ukryci urogouie zagrażali uszystkiemu, od podstau państwa i społeczeństua po kościec moralny i czystość rasową narodu. Naród musiał walczyć na śmierć i życie”27. Określenie, którego używał do nazwania zbiorowego „wroga”, brzmiało: „zorganizowane siły podludzi”28. Termin ten, niezuykle pojemny i w żaden sposób nie ograniczający każdego, kto po niego sięgał był często wykorzystywany.

${ }^{20}$ Przykłady jej stosowania wielokrotnie znajdziemy na kartach „Dzienników” V. Klemperera i jego książki: LTI. Notatnik filologa, Wydawnictwo Aletheia, Warszawa 2014 (ostatnie uydanie w Polsce).

${ }^{21}$ I. Kershaw, Hitler 1889-1936. Hybris, Dom Wydawniczy Rebis, Poznań 2001, s. 214; trzeba jednak pamiętać, że do zmiany brzmienia uspominanej zbitki słownej doszło w okresie zakreślonej datami trwania taktycznego sojuszu z ZSRR (1939-1941); więcej na ten temat w dalszej części rozważań.

${ }^{22}$ Zob. więcej na ten temat: E.C. Król, Propaganda i indoktrynacja narodowego socjalizmu..., op. cit., s. 87.

${ }^{23}$ Zob. też uyjaśnienie słowa „układ”, na które zwrócił uwagę podczas analizy języka propagandy PRL drugiej połowy lat 70. XX wieku M. Głowiński w pracy Zła mowa..., op. cit., s. 106-107; warto też pochylić się przy tej okazji nad propagandową łączliwością słów „układ” i „system”; jak pisze tłumacz „Dzienników” V. Klemperera w przypisach do roku 1933 o słowie „system” używanym u propagandzie NSDAP: „W języku narodouych socjalistów pogardliue określenie konstytucji Republiki Weimarskiej; czasy Systemu = lata Republiki Weimarskiej (1918-1933); zob. A. i A. Klubowie (tłum.), przypisy do roku 1933, s. 93.

${ }^{24}$ V. Ullrich, op. cit., s. 408.

${ }^{25}$ Była to opinia przywódcy SS wyrażona w kontekście masouyych zwolnień więźnióu z nazistouskich obozów w 1934 roku, na fali pewnej odwilży w polityce weunętrznej Hitlera, z którą Reichsfuhrer nie do końca się zgadzał; zob.: N. Wachsmann, KL. Historia nazistowskich obozów koncentracyjnych, Świat Książki, Warszawa 2016, s. 107.

${ }^{26}$ N. Wachsmann, op. cit., s. 107.

27 Ibidem.

${ }^{28}$ Ibidem. 
W pewnym momencie Himmler widział u tym zbiorze, cytując badacza: „komunistów, socjalistów, masonów, księży, elementy aspołeczne, kryminalistów i przede uszystkim Żydów, których «nie powinno się uważać za przedstawicieli naszego gatunku»"29.

Innymi zauważonymi $w$ języku propagandy Niemiec hitlerouskich typami tak zwanych wrogów wewnętrznych byli między innymi: „liberalistyczni” wrogowie ${ }^{30}$, „krytykanci”, „panikarze”, „grube ryby”, „szychy”, „monokle” ${ }^{1}$. Część z tych określeń stosowano wymiennie. Miały one charakteryzować członków tak zwanego systemu weimarskiego, w tym środowiska kojarzone z arystokracją i ugrupowaniami monarchistycznymi; w innym wypadku piętnować niebezpieczne dla rządzących III Rzeszą postawy społeczne ${ }^{32}$.

Interesującym przypadkiem jest nadanie nowego znaczenia, jednoznacznie negatywnego, pojęciu „liberalizm”, a zułaszcza pochodnym od niego wyrazom, w tym określeniu - „liberalistyczny”33. O tym zjawisku wielokrotnie pisał V. Klemperer, zwracając uwagę na upowszechniającą w tych działaniach językowo-interpretacyjnych rolę narodowych socjalistów ${ }^{34}$.

Dla Hitlera, który uważał wojnę prowadzoną na „froncie ojczyźnianym”35 za nie mniej ważną niż na frontach wojskowych, gdzie walczono z wrogami zewnętrznymi, miało być to uzasadnione doświadczeniami z lat I wojny światowej. On, jak i wielu Niemców, winę za klęskę w tym konflikcie przypisywali w znaczącym stopniu tak zwanemu ciosowi w plecy, za zadaniem którego stać mieli między innymi „niemieccy Żydzi, komuniści, socjaldemokraci, defetyści i inni zdrajcy"36.

W zestawie urogów zewnętrznych, w każdym razie działających na Wschodzie po 1941 roku, szczególne miejsce przypadło „komisarzowi”. Jak pisze badacz: „Hitler i jego generałowie mieli obsesję na punkcie radzieckich komisarzy spośród wszystkich

${ }^{29}$ Ibidem. Taki sposób mówienia o Żydach był konsekwencją występowania jednego z fundamentalnych dla ideologii nazistouskiej składnika, jakim było postawienie w jej centrum problemu rasy; zob. rozuażania na ten temat m.in.: A. Michnik, Przedmowa [w:] V. Klemperer, Chcę dawać świadectwo..., t. 1, op. cit., s. VII; I. Kershaw, Hitler 1889 - 1936..., op. cit., s. 109. ${ }^{30}$ V. Klemperer u kontekście ukazania się kolejnej książki Tomasza Manna zapisał u styczniu 1934 roku, że „prasie nie wolno pisać o takim podejrzanym liberalistycznym autorze”, a same słowo „liberalistyczny” uznał za chętniej używane u prasie niemieckiej niż już zużyte „marksistouski"; zob. V. Klemperer, Chcę dawać świadectwo.., t. 1, op. cit., s. 101.

${ }^{31}$ Zob.: ibidem, s. 104, 127; I. Kershaw, Hitler 1941-1945. Nemezis, Dom Wydauniczy Rebis, Poznań 2003, s. 288.

32 Słowami „krytykanci” i „panikarze” posługiwano się również często w języku propagandy Polski stalinowskiej.

${ }^{33}$ V. Klemperer uyjaśnił to u taki sposób: „Dlaczego «liberalistich» [liberalistyczny] ma znaczenie pejoratywne, «sozialistich» [socjalistyczny] neutralne? W rzeczywistości końcóuka «istich» w obu wypadkach działa zawężająco, wnosi element połowiczności, jakiegoś «jak gdyby». Liberalny to tyle, co hojny. Zatem liberalnym, także w sensie politycznym, jest ten, kto zausze i pod każdym uzględem postępuje hojnie lub tolerancyjnie. Natomiast liberalistyczny to taki, który tylko sprawia wrażenie, że jest liberalny"; zob. V. Klemperer, Chcę dawać świadectwo aż do końca. Dzienniki 1939-1942, t. 2, TAiWPN Universitas, Kraków 2000, s. 361.

34 Zob. m.in. jego rozważania: ibidem, s. 347, 361.

${ }^{35}$ Chodziło tutaj o działania prowadzone $\mathrm{w}$ kraju.

${ }^{36}$ N. Wachsmann, op. cit., s. 226; zob. też I. Kershaw, Hitler 1889-1936, op. cit., s. 117. 
urogów, którzy czyhali na uschodzie, komisarz był najbardziej złowieszczą, niemal demoniczną postacią. Byli przekonani, że dzicy i fanatyczni komisarze będą zmuszać swoich ludzi, aby walczyli do końca i dopuszczali się niewysłowionych aktów okrucieństwa wobec żołnierzy niemieckich"37. W już innych okolicznościach, gdy zbliżał się koniec wojny, a elementem polityki obronnej w Niemczech uczyniono tak zwaną propagandę grozy, „komisarz” służył wzmaganiu strachu i tym samym wzrostowi siły oporu przed najeźdźcami. Jak zapisał w lutym 1945 roku V. Klemperer:

[...] żeby kontynuować antyrosyjską propagandę grozy, rozgłasza się obecnie (my też już to słyszeliśmy), że żołnierze rosyjscy ostrzegają ludzi: «My wam nic nie zrobimy, ale uciekajcie, bo za nami idzie komisarz!». Komisarz, to oczywiście «żydousko-bolszewicki komisarz», krwawa bestia ${ }^{38}$.

Należy w tym miejscu zwrócić jeszcze uwagę na inny, ulokowany zasadniczo poza Niemcami, charakterystyczny dla III Rzeszy obiekt koncentracji negatyunej propa-

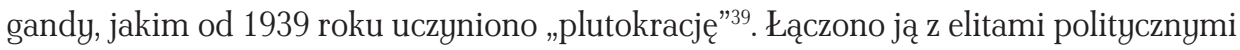
i gospodarczymi takich państw, jak: Wielka Brytania, Francja, Stany Zjednoczone, czy też rzadziej z państwem sowieckim, za którym też mieli stać „plutokraci” - co wyraźnie podkreślano - zuiązani z tak zwanym międzynarodouym żydostwem. Jak pisał E.C. Król, „elity” te przedstawiano jako opanowane przez żądzę pieniądza, pałające chęcią podporządkowania sobie świata, nawet przy użyciu siły ${ }^{40}$. Co interesujące, gdy wielka polityka Niemiec skierowała się przeciwko Zachodowi, a na moment uznała państwo sowieckie za sojusznika (od lata 1939 r.) pojęcie plutokracji u masowej propagandzie znalazło swoje nowe zastosowanie - pisano i mówiono wtedy o „żydowskiej plutokracji”. Victor Klemperer jesienią 1939 roku o tej nowej cesze języka nazistowskiego napisał: „Obecnie wrogiem jest żydouska plutokracja - a nie, jak do tej pory, «żydouski bolszewizm» - i to ona zwalcza niemiecki rząd narodowy"41.

W katalogu wrogów zewnętrznych nie zabrakowało również Polski i Polaków. Z tym, że masową i zorganizowaną odgórnie medialną kampanię na nowo rozpętano wiosną 1939 roku, gdy rząd Polski ostatecznie odmówił uspółpracy z Niemcami na warunkach stawianych przez nazistów. Sposób budowy antypolskiej kampanii i jej przebieg, także w okresie II wojny światowej, omówił szczegółowo Król ${ }^{42}$. Można tylko w tym miejscu przytoczyć dobrze oddającą stan umysłu Hitlera z okresu poprzedzającego wybuch

\footnotetext{
${ }_{37}$ N. Wachsmann, op. cit., s. 291-292.

38 V. Klemperer, V. Klemperer, Chcę dawać świadectwo, t. 3, op. cit., s. 414.

39 Słowo „plutokracja” była negatyuną wariacją - odmianą pojęcia „demokracja”, za którym to określeniem miała stać m.in. „figura międzynarodowego Žyda”.

${ }^{40}$ E.C. Król, Propaganda i indoktrynacja narodowego socjalizmu..., op. cit., s. 466-467.

${ }^{41}$ V. Klemperer, Chcę dawać świadectwo..., t. 2, op. cit., s. 40; dalsze rozważania na ten temat Klemperera na dalszych stronach „Dzienników”; zob. m.in. w tomie 2 (s. 235).

${ }^{42}$ Najpełniejszą jak dotąd charakterystykę $\mathrm{w}$ polskich badaniach naukouych na ten temat przedstawił E.C. Król w swojej książce pt. Polska i Polacy w propagandzie..., op. cit.
} 
Figura wroga w ideologii i propagandzie XX-wiecznych totalitaryzmów...

II wojny światowej myśl, który o relacjach z uschodnim sąsiadem mówił: „Wreszcie kończy się przyjaźń z «Polaczkami», którzy «są i pozostaną naszymi urogami»" ${ }^{3}$.

\section{Wróg i jego kategorie w polityce propagandowej reżimu komunistycznego}

Jeden z badaczy, próbując przybliżyć intelektualne początki poustania metafory uroga w obrębie ideologii komunistycznej, pisał:

Genezy bolszewickiej metafory wroga jako antytezy metafor partii oraz wodza szukać należy już w okresie narodzin interesującej nas doktryny bolszewików. Jej korzenie tkwiły niewątpliwie u samym marksizmie. Formułując hasło walki klas jako siły napędowej historii, narzędzia postępu, twórcy materializmu historycznego rozpatrywali historię przez pryzmat nieustannego konfliktu między klasami uciskającymi i uciskanymi. [...] Już klasyczny marksizm odwoływał się wprost do idei wroga klasowego, z którym można było zawierać koniunkturalne sojusze, ale, co ważne $u$ finalnej perspektywie, nie było możliwości zawarcia z nim jakiegokolwiek kompromisu ${ }^{44}$.

Trzeba też się zgodzić z następną konstatacją tego autora, który dalej stwierdził: „Środowisko bolszewików, a przede uszystkim sam Lenin, od początku starało się budować swój autoportret ideologiczny w silnej opozycji wobec swoich przeciuników politycznych, wykorzystując prostą zasadę podziału «my» - «oni»" ${ }^{2}$.

Już w pierwszych dniach po przejęciu władzy w Rosji przez bolszewików w listopadzie 1917 roku Feliks Dzierżyński na spotkaniu z delegacją przedstawicieli sowietów wiejskich, przybyłych do Piotrogrodzkiego Komitetu Wojskowo-Rewolucyjnego (PKWR) z guberni pskowskiej, mówi o potrzebie walki przeciu wrogowi klasowemu i wrogom ludu ${ }^{46}$.

Z kolei wykładnię stalinowskiego pojmowania figury wroga w Polsce powojennej dawała opublikowana w 1938 roku „święta księga stalinizmu”, czyli „Historia Wszechzwiązkowej Komunistycznej Partii (bolszewików). Krótki kurs”" Koncepcja

${ }^{43}$ Cyt. za: Ten straszny rok 1939. Z Prof. Włodzimierzem Borodziejem rozmawia Paweł Wroński, „Gazeta Wyborcza”, 3 IX 2009, s. 10.

${ }^{44}$ R. Stobiecki, Bolszewizm a historia. Próba rekonstrukcji bolszewickiej filozofii dziejów, Wydawnictuo Uniwersytetu Łódzkiego, Łódź 1998, s. 141-142.

45 Ibidem, s. 142.

${ }^{46}$ N. Werth, Państwo przeciw społeczeństwu. Przemoc, represje i terror w Związku Sowieckim [w:] Czarna księga komunizmu..., op. cit., s. 70.

47 Zob.: Historia Wszechzwiazkowej Komunistycznej Partii (bolszewików). Krótki kurs, Książka i Wiedza Warszawa 1949; oto co o tej księdze pisał Leszek Kołakouski: „„Krótki kurs» ustanowił nie tylko cały schemat bolszewickiej mitologii, łącznie z kultem Lenina i Stalina, ale także dokładnie zrytualizowane reguły tego kultu: wiadomo było od tej pory, że omawianiu uszystkich zagadnień, o jakich książka traktuje, partyjni pisarze, historycy i propagandziści nie mogą odstąpić od żadnej formuły skanonizowanej i obowiązani są poutarzać literalnie uszystkie wyrażenia dzieła. «Krótki kurs» - jak pisał dalej Kołakouski - nie był po prostu książką historyczną pełną faktów, ale potężną instrukcją społeczną: jednym z najważniejszych instrumentów, 
tego dzieła opierała się na spiskowej teorii dziejów. Według „Krótkiego kursu” wróg był wszechobecny. Jego istnienie stało się niezbędnym składnikiem opisu przeszłości i teraźniejszości ${ }^{48}$. O książce tej pisano, że jedną z najważniejszych właściwości tekstu było opisywanie „Epopei walki z heretykami”49 , do których Stalin zaliczył wszystkich, którzy próbowali mu się przeciustawić z Lwem Trockim na czele.

W pracy tej, opublikowanej w powojennej Polsce w roku $1949 \mathrm{w}$ ponad milionowym nakładzie, został zawarty kanon słownictwa, za pomocą którego opisywano świat. O walce partii z różnego rodzaju wrogami mówiły następujące czasouniki: dobić - rozgromić (bodaj najczęściej pojawiający się czasounik u całej książce), rozbić, znieść ze suej drogi, zadać druzgocący cios, bić, dać odprawę, rozprawić się, zdzierać maskę, obalić, demaskować, gromić, uygnać, znieść, zniszczyćco ${ }^{5}$. Jak pisze językoznawca:

Wszystkie te formuły mają zabarwienie zdecydowanie pozytywne, gdy stosują się do poczynań bolszewików [...]. Niektóre z czasowników odnoszą się wprawdzie róunież do działań przeciuników, przede wszystkim do aparatu carskiego i wówczas mają, oczywiście konotacje negatyune, ale - co charakterystyczne - nie ma to żadnego wpłyuu na używanie tych słów wówczas, gdy dotyczą czynów dokonywanych przez bolszewików, nawet rozgromienia dzielą się na słuszne i niesłuszne ${ }^{51}$.

Podobną do tej listy sporządza badacz dla używanych w tej książce formuł określających działania „wroga-heretyka”, który miał: „przemycać, sprytnie zmieniać oblicze, staczać się, usiłować sklecić, obrzucać błotem, zrzucać z siebie «demokratyczną» maskę, ujawniać suoje prawdziwe oblicze, maskować, oszukiwać lud, pomagać burżuazji, wyłazić ze skóry, by niweczyć, robić krecią robotę i tak dalej”52.

Na wroga numer jeden w latach 30. XX wieku wyrósł Lew Trocki, pozostający od lat 20. w długoletnim konflikcie ze Stalinem. Ocenia się, że następca Lenina zuracał większą uwagę na niebezpieczeństwa, płynące ze strony wrogów wewnętrznych niż zewnętrznych, co wyrazić się miało szeregiem procesów politycznych sfingowanych na życzenie Stalina, w wyniku których zamordowani zostali między innymi: Nikołaj Bucharin, Lew Kamieniew, Grigorij Zinowiew czy też marszałek Michaił Tuchaczeuski, osoby przez wiele lat uchodzące w odbiorze masouym za przywódców rewolucji ${ }^{53}$.

za pomocą których partia miała sprawować uładzę nad umysłami i niszczyć zarówno myślenie krytycznie, jak pamięć społeczeństua o własnej przeszłości”; zob. L Kołakouski, Główne nurty marksizmu, Wydawnictwo Aneks, Londyn 1988, s. 865.

${ }^{48}$ Zob.: J. Tazbir, Protokoły Mędrców Syjonu. Autentyk czy falsyfikat?, Interlibro, Warszawa 1992, s. 9; A.F. Grabski, Święta księga stalinizmu [w:] Pochwała historii powszechnej. Studia ofiarowane prof. A. Bartnickiemu, OSA UW, Warszawa 1996, s. 220.

${ }_{49}$ M. Głowiński, „Nie puszczać przeszłości na żywioł”, „Krótki kurs WKP(b)” jako opowiadanie mityczne [w:] M. Głowiński, Rytuat i demagogia. Trzynaście szkiców o sztuce zdegradowanej, Wydawnictwo Open, Warszawa 1992, s. 31-37.

${ }^{50}$ Ibidem..., op. cit., s. 34.

${ }^{51}$ Ibidem.

${ }^{52}$ Ibidem.

53 Zob. R. Stobiecki, op. cit., s. 150. 
Co znamienne, w latach 1939-1941 z repertuaru wrogów zewnętrznych zostaje wykreślona „faszystowska agentura”, będąca obok tak zwanego zgniłego liberalizmu państu zachodnich podstawowym zagrożeniem zewnętrznym dla Związku Radzieckiego.

Lata 30. to róunież czas występowania w propagandzie sowieckiej zjawiska „unifikacji” wroga, polegającego na takim przedstawianiu przeciuników, by potencjalnym odbiorcom jawili się jako „diabelska siła, ukryta i uszechobecna, działająca jednocześnie wewnątrz i na zewnątrz kraju” w postaci - jak pisano - „wrogów uszelkiej maści, faszystów, trockistów, szpiegów i sabotażystów" ${ }^{4}$. Pewne wątki z tak pojmowanej figury wszechobecnego wroga czerpano do opisu go wiele lat później, między innymi w Polsce 1968 roku, gdzie o domniemanych i bardziej konkretnych sprawcach pisano jako o „urogach uszelkiej maści”, zagrażających już nie tylko klasie robotniczej, ale Polakom u ogólności ${ }^{55}$.

W literaturze przedmiotu zuraca się uwagę na uystępowanie w okresie stalinizmu procesu „teatralizacji” metafory uroga i zmianie towarzyszącej jej symbolikii ${ }^{56}$. Procesy z lat 30. ubiegłego wieku z dużym rozmachem wyreżyserowane i nagłośnione miały być swoistym dramatycznym przedstawieniem, gdzie role były z góry podzielone, gdzie zdrowe siły narodu z organami ścigania na czele odkrywają wszechobecnych, spiskujących wrogów, by ostatecznie przez swe działania zmusić ich do przyznania i tym samym przedstawienia ZSRR jako „oblężonej twierdzy”, otoczonej przez zeunętrznych i wewnętrznych nieprzyjació ${ }^{57}$. Inną nauką wypływającą z tak przeprowadzonego dowodu zbrodni miało być przekonanie mas, że i tak w ostatecznym rozrachunku wrogowie stoją zawsze na przegranych pozycjach, gdyż w konfrontacji z nieubłaganą logiką historii i potężnymi strukturami partii-państwa, wreszcie siłą moralną zawartą z naukach marksizmu - leninizmu, szans na zuycięstwo nie mają, ponieważ zausze będzie to tylko kwestią czasu, kiedy zostaną zdemaskowani i publicznie potępieni.

Rumuński badacz Mircea Eliade dostrzegał w komunistycznym mówieniu o wrogu występowanie pewnych kategorii, charakterów i archetypów wroga, między innymi „trockisty, zwolennika Tity, mordercy, agenta imperializmu”, do których to system niejako automatycznie przypisywał w danym momencie i wybranym kraju ludzi, pewne zjawiska - które właśnie zostały uznane przez Stalina bądź poddanych mu krajowych przywódców partyjnych za wrogie ${ }^{58}$.

W praktyce propagandowej Polski pieruszych lat powojennych (1944/45-1947) zarysouruje się - potem stale obecna w działaniach propagandouych - maniera prezentowania przeszłości, teraźniejszości i przyszłości w kontekście obrazu duubiegunouego świata. Jeszcze $w$ trakcie truania wojny rolę uniwersalnego wroga pełniły faszystowskie

\footnotetext{
${ }_{54}$ B. Baczko, Wyobraźnia społeczna, wyobrażenia społeczne [w:] idem, Wyobrażenia społeczne. Szkice o pamięci zbiorowej, Wydaunictwo Naukowe PWN, Warszawa 1994, s. 68. ${ }_{55}$ M. Głowiński, Figura wroga (O propagandzie marcowej) [w:] idem, Nowomowa po polsku, Warszawa 1991, s. 65; zob też: J. Wojsław, „Polityka” Mieczysława Rakowskiego..., op. cit.

${ }^{56}$ R. Stobiecki, op. cit., s. 152-153.

57 B. Baczko, Wyobrażenia społeczne..., op. cit., s. 153.

${ }^{58}$ M. Eliade, Religia, literatura i komunizm. Dziennik emigranta, Puls Publications, Londyn 1990, s. 224.
} 
Niemcy i ich sojusznicy. Wraz z instalowaniem władzy komunistów u Polsce ugruntowano za pomocą środków masowego oddziaływania obraz świata, a zułaszcza Polski, oparty na przedstawianiu rzeczywistości w opozycji do ustroju i państwa realnego socjalizmu. Wszystko to, co było związane z modelem sowieckim, jeżeli nawet w pieruszym okresie funkcjonowania PRL, nie powoływano się tak otwarcie na przykład uschodniego sąsiada, uznawano za właściue i godne upouszechniania, natomiast będące do tego w opozycji, w tym realnych i wyimaginowanych przeciuników Polski Ludowej zaliczano do urogów ustroju ${ }^{59}$. W pierwszych latach istnienia Polski realnego socjalizmu byli to między innymi obszarnicy i kapitaliści, oficerowie i rzadziej żołnierze polskiego, antykomunistycznego podziemia, rząd londyński i grupy go popierające w kraju i za granicą, i w niedługim okresie przywódcy mikołajczykouskiego PSL.

Wraz z upływem czasu repertuar oficjalnych wrogów zyskuje swój stabilny kształt. Dotyczy to okresu trwania polskiego stalinizmu, który większość badaczy lokuje u granicach lat 1949-1954/55 ${ }^{60}$. W tym czasie nie tylko lista przeciuników nowej Polski zostaje ugruntowana, ale także sposób ich opisu nabiera cech truałych ${ }^{61}$.

Analizując przekazy propagandowe z przełomu lat 40. i 50. ubiegłego wieku, można uyróżnić co najmniej kilka kategorii figury uroga. Oprócz tak dobrze znanego podziału na wrogów zewnętrznych i wewnętrznych pojawiały się też określenia mówiące o „wrogach ideologicznych”; w tym wypadku z zasady odnoszące się do przeciuników działających z ukrycia i ulokowanych wewnątrz państu i partii komunistycznych. Kolejnym określeniem było sformułowanie „wrogowie państwa i narodu”, które z kolei umożliwiało dość suobodne posługiwanie się nim, gdyż do tej kategorii mogli zostać zaliczeni, w zależności od aktualnych potrzeb politycznych, przedstawiciele wszystkich pozostałych kategorii i podkategorii.

Na liście urogów zewnętrznych czołoue miejsca, co zrozumiałe ze uzględu na narastanie zimnej wojny, przypadły państwom kapitalistycznym, ich elitom i tworzonym przez nie sojuszom. Często u propagandzie podkreślano przodującą rolę imperializmu amerykańskiego, nieraz nazywanego anglo-amerykańskim ${ }^{62}$. Niemniej ważną pozycję miały pełnić u tym zestawieniu Niemcy Zachodnie ${ }^{63}$, których politykę określano uyra-

${ }_{59}$ Dobrze opisuje ogólne zasady propagandy pieruszego powojennego 10-lecia Polski Ludowej fragment z „Dzienników” Leopolda Tyrmanda, który w charakterystyczny dla siebie sposób wymienił podstawowe techniki prezentowania rzekomego obrazu rzeczywistości u prasie; zaliczył do nich m.in. uszechobecne, na zasadzie czarno-białej: poróunywanie państw kapitalistycznych z socjalistycznymi; Polski przedwojennej z powojenną; zob. L. Tyrmand, Dzienniki 1954, Res Publica, Warszawa 1989, s. 188.

${ }^{60}$ Zob. więcej na ten temat w: J. Wojsław, Obraz teraźniejszości w propagandzie..., op. cit., s. $10-11$.

${ }^{61}$ Ibidem, s. 126-214.

${ }^{62}$ Uzupełnieniem negatywnego wizerunku Zachodu, w peunym sensie synonimem ,zgniłego liberalizmu" był w polskiej propagandzie lat stalinizmu bikiniarz, którego już sam uygląd, czyli sposób ubierania, uczesania, a zułaszcza zachowania miał przedstawiać zepsucie moralne panujące w społeczeństwach państu imperialistycznych.

${ }_{63}$ Oficjalna nazwa państua niemieckiego poustałego w 1949 roku, z połączenia trzech zachodnich stref okupacyjnych, brzmiała Republika Federalna Niemiec (RFN); w Polsce Ludowej do 1970 
Figura wroga w ideologii i propagandzie XX-wiecznych totalitaryzmów...

żeniem - „rewizjonizmu zachodnioniemieckiego”, którym zresztą straszono Polaków przez cały okres istnienia PRL ${ }^{64}$. W odniesieniu do grupy tych państu używano zurotu „podżegacze wojenni” czy też „obóz wojny”, uwypuklając w ten sposób istnienie „obozu pokoju”, na którego czele stać miał Związek Radziecki i którego ważnym członkiem była Polska Ludowa.

Niejako na pograniczu kategorii został umieszczony przywódca socjalistycznej Jugosławii Josip Broz-Tito. Wywodził się on z uspólnego dla komunistów pnia ideologicznego, by nagle, za sprawą konfliktu ze Stalinem (od 1948 r.), stać się dla pozostałych państu bloku sowieckiego postacią wyklętą, oskarżoną o uspółpracę z obozem państu imperialistycznych i faszystouskich, o którym pisano do 1954 roku, że jest „agentem imperialistów, podżegaczy wojennych i szpiegów”

Katalog wrogów wewnętrznych był bogatszy i bardziej kategoryzacyjnie złożony. W zespole tym znaleźli się między innymi nieodlegli uspółpracounicy aktualnych przywódców państu bloku sowieckiego, w tym wcześniej uspominani liderzy partyjni ZSRR z Trockim na czele, jak również ich lokalni odpowiednicy w krajach podporządkowanych Moskwie po 1945 roku, jak np. w Polsce zualczany przez środowisko polityczne Bolesława Bieruta Władysław Gomułka i kojarzone z nim postacie. W języku propagandy reprezentowane przez niedawnego przywódcę PPR poglądy nazywano „odchyleniem prawicowo-nacjonalistycznym”, a oskarżonych o sprzyjanie mu polityków określano „agentami prawicy socjal-demokratycznej, dywersantami prawicowo-socjalistycznymi”"66.

Do kategorii urogów wewnętrznych zaliczono również rzekomych gospodarczych sabotażystów, w tym: kułaków na usi, bumelantów i marnotrawców w zakładach pracy, spekulantów handlujących walutą i deficytowymi towarami w kraju.

Wrogami wewnętrznymi, bo działającymi w Polsce i będącymi obywatelami PRL, mieli być także, oskarżani o działalność szpiegouską i dywersyjną na rzecz państu zachodnich, duchowni, dawni oficerowie Narodowych Sił Zbrojnych, Armii Krajowej i Polskich Sił Zbrojnych na Zachodzie; osoby w Polsce przedurześniowej należące do tak zuanej klasy kapitalistów, dawni posiadacze ziemscy, właściciele zakładów pracy, sklepikarze i tym podobni.

Nie można też zapomnieć o jednym z kluczouych tematów propagandy lat panowania stalinizmu u Polsce, jakim z końcem lat 40. ubiegłego wieku uczyniono Kościół. Negatyunymi bohaterami stawali się hierarchowie Kościoła, jak również pojedynczy

roku używano nazuy Niemiecka Republika Federalna (NRF), a także w formie publicystycznej, do 1990 roku - Niemcy Zachodnie.

${ }^{64}$ Zob. E.C. Król, Wizerunek Niemca etnicznego w polskim filmie po II wojnie światowej, „Przegląd Historyczny” 2005, z. 1.

${ }_{65}$ Zob. m.in. użyte w dokumentach archiwalnych KC PZPR, Wydziałów Propagandy i Agitacji oraz Wydziału Prasy i Wydawnictu KC PZPR z przełomu lat 40. i 50. sformułowania mówiące o wrogach Polski Ludowej; zob.: Archiwum Akt Nowych (dalej: AAN), Komitet Centralny Polskiej Zjednoczonej Partii Robotniczej (dalej: KC PZPR), sygn. 237/VIII/ 68, k. 1; AAN, KC PZPR, 237/XIX/63, k. 3.

${ }^{66}$ Ibidem. 
Jacek Wojsław

duchouni, poszczególne zgromadzenia zakonne oraz organizacje kościelne, gromadzące także osoby z laikatu, i przez cały okres Watykan uosabiany przez papieża Piusa XII ${ }^{67}$.

\section{Podsumowanie}

Dokonanie prostej wykładni komunistycznej filozofii tworzenia repertuaru i kategoryzowania „wrogów” nie jest rzeczą prostą. W zależności od zmieniających się potrzeb przywódcy komunistyczni stanowili instancję ostateczną, która zakreślała czas, metody i co najważniejsze przedmiot ataków propagandowych. Podobnie sytuacja wyglądała w perspektywie próby budowania modelu hierarchizacji wrogów. I tutaj swoista gradacja ulegała częstej fluktuacji. Trzeba jednak pamiętać, że wachlarz „wrogów” i sposób ich prezentowania przez mass media komunistyczne był w miarę stabilny dla podokresów zakreślonych latami sprawowania rządów przez poszczególnych I sekretarzy (generalnych sekretarzy).

Nieco inaczej przedstawiała się ta kwestia w wypadku ruchu nazistowskiego. Tutaj od samego początku i do końca trwania III Rzeszy prym w „nastawianiu” ideologiczno-propagandowym wiodła jedna postać, przywódca ruchu, a następnie dyktator Niemiec - Adolf Hitler. Do czołowych współpracowników na tak zwanym froncie ideologicznym należeli Joseph Goebbels i Alfred Rosenberg. Podobna jednak w przypadku obu modeli totalitaryzmów była zasada kreowania, bądź też uygaszania (także czasouego) propagandowych ataków, w zależności od aktualnych interesów poszczególnych reżimów niedemokratycznych.

Bez względu na odmianę systemu totalitarnego, ani jego brunatna, ani czerwona wersja nie mogłaby zdobyć władzy, a na pewno tej władzy utrzymać w krótszym lub dłuższym czasie bez wykreowania w przestrzeni publicznej przysłowiowej figury wroga. „Wróg i wrogowie” stanowili niezbędną pożywkę dla systemu politycznego, opartego w znacznym stopniu na obronie i walce z mniej lub bardziej konkretnymi przeciunikami nowego ustroju, w każdym razie u sferze medialnej. Król „produkowanie «obrazów uroga»” zaliczył do jednych z podstawowych zadań systemu propagandy i indoktrynacji Trzeciej Rzeszy ${ }^{68}$. Nie inaczej, jak się wydaje, wyglądała sytuacja w reżimie komunistycznym.

Jak trafnie napisała Krystyna Kersten: „Wszelkie totalitarne ideologie i systemy wprowadzają pojęcie uroga, którego należy zniszczyć u imię jakiegoś «dobra»" ${ }^{69}$. Przekonanie to zostaje wpisane $w$ system totalitarny, co $w$ praktyce oznaczało tłumaczenie wielu posunięć władz (także na etapie walki o władzę), zwłaszcza tych, które w konsekwencji prowadziły do obniżenia standardów życia i różnych codziennych niedogodności, sytuacją spowodowaną działaniami mniej lub bardziej cielesnego przeciunika.

\footnotetext{
${ }^{67}$ Zob. więcej na ten temat (tam też podana literatura przedmiotu) w: Ł. Marek, „Kler to nasz wróg": polityka władz państwowych wobec Kościoła katolickiego na terenie województwa katowickiego w latach 1956-1970, Studio NOA Ireneusz Olsza, Katowice 2009.

${ }^{68}$ E.C. Król, Propaganda i indoktrynacja narodowego socjalizmu..., op. cit., s. 512.

${ }^{69}$ K. Kersten, Wstęp do polskiego wydania..., op. cit., s. 17.
} 
Figura wroga w ideologii i propagandzie XX-wiecznych totalitaryzmów...

Kategoryzacja urogów, mimo że przy różnych okazjach jej dokonywano, w praktyce polityczno-propagandowej nie odgrywała, jak się wydaje, aż tak ważnej roli w obu odmianach reżimów totalitarnych. W tym kontekście warta jest zacytouania opinia jednego z badaczy historii III Rzeszy, który napisał, że:

[...] reżim [ten - J.W.] nigdy nie przeprowadzał ścisłego rozgraniczenia suoich wrogów, a im dłużej utrzymywał się u władzy, tym bardziej kategorie wrogów rasowych, politycznych i z marginesu społecznego stapiały się w świadomości nazistouskich przywódców w jedną całość; pod koniec uojny Heinrich Himmler móuił o «żydousko-komunistycznej organizacji aspołecznej» ${ }^{70}$.

W ideologii nazistouskiej i następnie w praktyce funkcjonowania III Rzeszy na pierwsze miejsce wysuwała się walka z Żydami i „międzynarodowym żydostwem”, które miało stać, zdaniem Hitlera, zaróuno za globalnym kapitałem, jak i radzieckim bolszewizmem - drugim kluczowym obiektem koncentracji propagandy, który traktowano również jako symbol „wroga światowego”. Wreszcie trzecim charakterystycznym elementem obowiązującej po 1933 roku triady wrogów (szczególnie od wiosny 1939 r.) stała się tak zwana plutokracja, do której zaliczano „kapitalistów” reprezentowanych przede uszystkim przez elity polityczne i gospodarcze Wielkiej Brytanii, Francji i USA, co podkreślano - również mocno spenetrowane przez środowiska żydouskie ${ }^{71}$.

Z kolei w odmianie totalitaryzmu sowieckiego i reżimów po 1945 roku mu podległych, komuniści najuiększego niebezpieczeństwa upatrywali w faszyźmie - i jak pisze Norman Davies - „pieskim kapitalizmie”, „kułakach” i „domniemanych sabotażystach”72. Oczywiście zestaw wrogów był dużo szerszy, w zależności od kraju i okresu, który będzie się analizować.

Kończąc te rozważania, należy podkreślić powody, dla których warto wracać w badaniach naukowych do omawianej problematyki. Wykorzystywanie w polityce propagandowej i szerzej w komunikacji politycznej przez reżimy niedemokratyczne tak zwanej figury wroga uydają się niestety zjawiskiem obecnym również uspółcześnie, także w systemach demokratycznych. Znajomość skutków, do jakich doprowadziły działania polityków, wiedza jak „produkowano” i następnie uykorzystywano obrazy rzekomych przeciwników państwa i narodu, i dzisiaj powinna dawać do myślenia.

Jak pisze badacz, w kontekście poszukiwania odpowiedzi na pytanie o celowość i sens poszerzania dzisiaj wiadomości na temat działalności J. Goebbelsa:

\footnotetext{
${ }^{70}$ N. Wachsmann, op. cit., s. 175.

${ }^{71}$ Stąd też nie tylko w przemówieniach i tekstach kolportowanych do niemieckiego odbiorcy, ale w często skuteczniej przemawiającej propagandzie wizualnej (karykatury, plakaty) ukazywano obraz Żyda panującego nad „plutokratycznym” światem, do którego zaliczano cały zbiór państu koalicji antyhitlerouskiej i przewodzące im elity, których symbolami uczyniono pouszechnie rozpoznawalnych przywódców „wielkiej trójki”; zob. więcej na ten temat m.in. w: Das Jahrhundert der Bilder1900 bis 1949, Herausgegeben von Gerhard Paul, Gottingen 2009, s. 412-713 (tam też podana obszerna literatura przedmiotu).

${ }^{72}$ N. Davies, op. cit., s. 1005.
} 
[...] w wielu krajach funkcjonują nadal, a dzięki coraz większej perfekcji technologicznej mass mediów wręcz rozwijają się u najlepsze praktyki wykorzystujące i doskonalące wzorce, metody i techniki propagandy totalnej. Można więc bez ryzyka wielkiej przesady stuierdzić, że po gabinetach szefów uspółczesnych agencji PR, marketingu, promocji i reklamy kołacze się duch Goebbelsa, nakłaniając do coraz większych uproszczeń, hałaśliwych nagonek i kłamliuych kampanii ${ }^{73}$.

A trzeba pamiętać, że uzyskiwane, także dzięki takim metodom, poparcie polityczne, gdy próbuje się wzniecić strach i lęk przed obcymi, odczłowieczyć przeciuników politycznych, może doprowadzić do władzy ruchy o skrajnych poglądach, niedbających o przestrzeganie zasad charakteryzujących demokratyczne państuo prawne.

\section{Bibliografia}

Arendt H., Korzenie totalitaryzmu, Śuiat Książki, Warszawa 2014.

Baczko B., Wyobraźnia społeczna, wyobrażenia społeczne [w:] idem, Wyobrażenia społeczne. Szkice o pamięci zbiorowej, Wydawnictwo Naukowe PWN, Warszawa 1994.

Bocheński J., Po co nam „Dzienniki” zbrodniarza, szefa propagandy Trzeciej Rzeszy, „Gazeta Wyborcza", 5-6 VII 2014, s. 24-26.

Bralczyk J., O języku polskiej polityki lat osiemdziesiątych i dziewięćdziesiatych, Trio, Warszawa 2003.

Bralczyk J., O języku polskiej propagandy politycznej lat siedemdziesiatych, Trio, Warszawa 2001.

Das Jahrhundert der Bilder 1900 bis 1949, Herausgegeben von Gerhard Paul, Gottingen 2009. Davies N., Europa. Rozprawa historyka z historia, Znak, Kraków 1998.

Eliade M., Religia, literatura i komunizm. Dziennik emigranta, Puls Publications, Londyn 1990. Głowiński M., Figura wroga (O propagandzie marcowej) [w:] idem, Nowomowa po polsku, PEN, Warszawa 1991.

Głowiński M., „Nie puszczać przeszłości na żywioł”, „Krótki kurs WKP(b)” jako opowiadanie mityczne [w:] M. Głowiński, Rytuat i demagogia. Trzynaście szkiców o sztuce zdegradowanej, Open, Warszawa 1992.

Głowiński M., Język siecze (rozmowa prowadzona przez Katarzynę Czarnecką), „Polityka”, 14 IX 2016, s. 24-25.

Głowiński M., Zła mowa. Jak nie dać się propagandzie, Wielka Litera, Warszawa 2016.

Grabski A.F., Święta księga stalinizmu [w:] Pochwała historii powszechnej. Studia ofiarowane prof. A. Bartnickiemu, OSA UW, Warszawa 1996.

Historia Wszechzwiązowej Komunistycznej Partii (bolszewików). Krótki kurs, Książka i Wiedza Warszawa 1949.

Kajtoch W., Bracia Strugaccy (zarys twórczości), TAiWPN Universitas, Kraków 1993.

Kersten K., Wstęp do polskiego wydania [w:] S. Courtois, N. Werth, J.-L. Panne, A. Paczkouski, K. Bartosek, J.-L. Margolin, Czarna księga komunizmu. Zbrodnie, terror, prześladowania, Prószyński i S-ka, Warszawa 1999.

Kershaw I., Hitler 1889-1936. Hybris, Dom Wydawniczy Rebis, Poznań 2001.

Kershaw I., Hitler 1941-1945. Nemezis, Dom Wydawniczy Rebis, Poznań 2003.

${ }^{73}$ E.C. Król, Joseph Goebbels i jego dzienniki..., op. cit., s. L. 
Figura wroga w ideologii i propagandzie XX-wiecznych totalitaryzmów...

Klemperer V., Chcę dawać świadectwo aż do końca. Dzienniki 1933-1938, 1939-1942, 1943-1945, t. 1-3, TAiWPN Universitas, Kraków 2000.

Klemperer V., LTI. Notatnik filologa, Wydawnictwo Aletheia, Warszawa 2014.

Kołakouski L., Główne nurty marksizmu, Wydawnictwo Aneks, Londyn 1988.

Kołakouski L., Zapiski podczłowieka z żóttą tata [w:] V. Klemperer, Chcę dawać świadectwo aż do końca. Dzienniki 1933-1938, t. 1, TAiWPN Universitas, Kraków 2000, s. XXIX-XXXVI.

Król E.C., Formuła wroga w polskim filmie socrealistycznym (1947-1956), „Przegląd Historyczny" 2007, z. 2.

Król E.C., Joseph Goebbels i jego „Dzienniki” [w:] Joseph Goebbels. Dzienniki, t. 1: 1923-1939, Warszawa 2013.

Król, E.C., Polska i Polacy w propagandzie narodowego socjalizmu w Niemczech 1919-1945, Instytut Studiów Politycznych Polskiej Akademii Nauk, Warszawa 2006.

Król E.C., Propaganda i indoktrynacja narodowego socjalizmu w Niemczech 1919-1945. Studium organizacji, treści, metod i technik masowego oddziaływania, Instytut Studiów Politycznych Polskiej Akademii Nauk-Rytm, Warszawa 1999.

Król E.C., Stowo do tomu trzeciego „Dzienników” Josepha Goebbelsa [w:] Joseph Goebbels. Dzienniki, t. 3: 1943-1945, Świat Książki, Warszawa 2014.

Król E.C., W poszukiwaniu modelu propagandy totalnej [w:] Propaganda w systemach demokratycznych i niedemokratycznych, red. J.W. Wołoszyn, Wydawnictwo KUL, Lublin 2015.

Marek Ł., „Kler to nasz wróg”: polityka władz państwowych wobec Kościoła katolickiego na terenie województwa katowickiego w latach 1956-1970, Studio NOA Ireneusz Olsza, Katouice 2009.

Stobiecki R., Bolszewizm a historia. Próba rekonstrukcji bolszewickiej filozofii dziejów, Wydawnictuo Uniwersytetu Łódzkiego, Łódź 1998.

Ten straszny rok 1939. Z Prof. Włodzimierzem Borodziejem rozmawia Paweł Wroński, „Gazeta Wyborcza", 3 IX 2009, s. 10.

Ullrich V., Hitler. Narodziny zła 1989 - 1939, Prószyński Media Sp. z o.o., Warszawa 2015.

Wachsmann N., KL. Historia nazistouskich obozów koncentracyjnych, Świat Książki, Warszawa 2016.

Wojsław J., Ideologizacja przekazów ikonograficznych o tematyce zdrowotnej $w$ czasach PRL: w poszukiwaniu wizualnego stereotypu, „Zeszyty Prasoznawcze” 2015, nr 2 (222), s. $405-422$.

Wojsław J., Obraz teraźniejszości w propagandzie komunistycznej Polski lat 1949-1954. Zarys problematyki, Wydawnictwo UG, Gdańsk 2009.

Wojsław J., „Polityka” Mieczysława Rakowskiego wobec „marcowej”(1968) mowy nienawiści [w:] Media, Biznes, Kultura. Społeczna i polityczna rola mediów, red. M. Łosiewicz, A. Ryłko-Kurpieuska, TrueSign-Novae Res, Kinvara Co. Galuay-Gdynia 2015. 
